\title{
Inhalable particulate matter burden in selected day-care centres in Ibadan, Nigeria
}

\author{
Godson R. E. E. Ana*, Zainab O. Umar \\ Department of Environmental Health Sciences, Faculty of Public Health, University of Ibadan, Ibadan, Nigeria
}

Email address:

anagrow@yahoo.com(G. R. E. E. Ana)

To cite this article:

Godson R. E. E. Ana, Zainab O. Umar. Inhalable Particulate Matter Burden in Selected Day-Care Centres in Ibadan, Nigeria. International Journal of Environmental Monitoring and Analysis. Vol. 1, No. 6, 2013, pp. 296-301. doi: 10.11648/j.ijema.20130106.14

\begin{abstract}
The indoor air quality in day-care centres may influence the occurrence of infectious diseases and increase the risk of non-communicable diseases. The World Health Organisation (WHO) and other international agencies have considered particulate matter as an indicator of impact of air pollution on human health yet information on this from childcare centres is poorly documented in developing countries. This study therefore was designed to assess the particulate matter concentration $\left(\mathrm{PM}_{10}\right)$ in selected day-care centres (DCCs) in Ibadan, South western Nigeria. The study was descriptive cross sectional. $\mathrm{PM}_{10}$ load was determined 3 days a week for 16 weeks spanning the late wet season and early dry season periods from 10 locations of the selected DCCs using a digital PM counter model Met one. The ratio of indoor/outdoor $\mathrm{PM}_{10}$ was computed. Results obtained throughout the monitoring period for all the locations were averaged and compared with WHO $\mathrm{PM}_{10}$ guideline limit of $50 \mu \mathrm{g} / \mathrm{m}^{3}$.Data collected were analysed using descriptive statistics and ANOVA at $5 \%$ level of significance. Mean indoor $\mathrm{PM}_{10}$ readings for wet season $\left(73.4 \pm 54.4 \mu \mathrm{g} / \mathrm{m}^{3}\right)$ and dry season $(296.3$ $\left.\pm 61.6 \mu \mathrm{g} / \mathrm{m}^{3}\right)$ significantly exceeded guideline limit $(\mathrm{P}<0.05)$. The indoor/outdoor $\mathrm{PM}_{10}$ ratio was $1.38 \pm 0.97$ and being greater than 1 indicated a possible indoor source of pollution. High particulate matter concentration observed is indicative of the poor indoor air quality condition in the day care centres. Government policies on routine air quality monitoring and stringent enforcement of environmental sanitation in day care centres are advocated.
\end{abstract}

Keywords: Day Care Centres, Indoor Air Quality, Particulate Matter, Seasonal Variation

\section{Introduction}

In Nigeria the transformation and change in structure of the labour force due to increased job opportunities occasioned by improved female education have resulted in the increased use of Day-care Centers (DCCs) by working mothers. DCCs are Early Child Development (ECD) centres usually for children aged 0-3 years [1] which provide non-parental care that complement and/or supplement those provided at home [2].

The quality of indoor air in schools, day-care centres or other private and public buildings where people spend a greater part of their life is an essential determinant of healthy life and people's well-being [3]. The hours spent in this environment exposes them to potentially harmful chemicals or pollutants. While exposures may be small, they can add up and, in combination, have the potential to contribute to asthma, learning disabilities, cancer and other chronic conditions [4].

Particulate matter (PM) has been recognized in recent years as the most dangerous and widely spread air pollutant [5]affecting more people than any other pollutant and contributing to the risk of developing cardiovascular and respiratory diseases, as well as lung cancer. Wet season has cleaning effects over the suspended particulate matter [6]. Developing countries account for $77 \%$ of all global particulate exposure, where numerous studies have found that IAP levels are typically many times higher than developed world standards for ambient air quality. Concentration levels vary greatly depending on the time of day, season and place of measurement, especially for inhalable particulates $\left(<\mathrm{PM}_{10}\right)$

$\mathrm{PM}_{10}$ is associated with increased mortality and morbidity in many cities worldwide and the risk is greatly pronounced among susceptible populations, including the elderly, children, and people with pre-existing health conditions [7]. Penard-Morand et al.[8] carried out a large population-based study of children from 108 randomly selected schools in 6 French cities, elevated concentrations 
of $\mathrm{PM}_{10}$ was significantly associated with an increased risk of suffering from allergic rhinitis, past year rhinoconjunctivitis and wheeze.

Numerous epidemiological studies[9, 10, 11, 12] such as Dockery et al., 1993; Peters et al., 1999; Schwartz \& Neas, 2000; LeTertre et al., 2002have demonstrated adverse impacts of PM exposures on mortality, pulmonary and cardiovascular health. Most of these investigations have relied upon outdoor PM concentrations as surrogates of human exposures. However, considering that children spend the majority of their time indoors, exposures to PM of outdoor origin may not be equal to exposures to indoor PM concentration levels. The outdoor penetration of PM into an urban CCC close to major traffic was studied in Finland [13]. They reported that PM10 from outdoor traffic readily penetrated indoors (indoor-outdoor ratio of 0.5 ).

A study by Laquatra et al, [14] in households and childcare facilities in the United States reported high levels of pollutants were observed in the childcare facilities, which raises questions about constant pollutant exposure to children. Other studies on day-care environment particularly on exposure to $\mathrm{PM}_{10}$ were carried out in Bangkok, Thailand which particularly, took cognizance of the density area [7]. Studies on seasonality in particulate matter were carried out in Malaysia [6] and in India [15]. Other studies on particulate matter were carried out by Massey et al.,[16]and Manadhar et al.,[5].The variety of unique features in design and usage of public and commercial buildings such as schools, apartment buildings, hospitals, and shopping malls make a wide range of IAQ problems possible. In developing regions limited number of studies has been conducted regarding indoor air quality (IAQ) and health [17].

Despite the growing importance of the day-care environment and the negative effect these environmental parameters may have on the children, studies on daycare centre environment and air quality parameters such as respirable particulate matter burden in daycare locations are still not well documented. This study was designed to assess the inhalable particulate matter $\left(\mathrm{PM}_{10}\right)$ load in selected daycare centres in Ibadan, South western Nigeria

\section{Material and Methods}

\subsection{Study Area}

The study was conducted in day care centres in Ibadan North Local Government Area of Ibadan, the capital city of Oyo State and the third largest metropolitan area in Nigeria, after Lagos and Kano, with a population of 1,338,659 according to the 2006 census [18]. Ibadan covers a land area of 12 kilometres radius with Mapo hall as the centre. Ibadan has a tropical wet and dry climate. Ibadan's wet season runs from March through October. November to February forms the city's dry season, during which Ibadan experiences the typical West African harmattan. The mean total rainfall for Ibadan is $1420 \mathrm{~mm}$, falling in approximately 109 days. The mean maximum temperature is $26.5^{\circ} \mathrm{C}$, minimum $21.4^{\circ} \mathrm{C}$ and the relative humidity is $74.6 \%$. The study focuses on day care centres in Ibadan North Local Government Area of Ibadan, Oyo state, Nigeria.

\subsection{Selection of Day-Care Centres}

Of the 48 day care centres identified in Ibadan North Local Government $20 \%$ of them approximately 10 were randomly selected by balloting for the air sampling.

\subsection{Determination of Meteorological Parameters}

A multi-tester meteorological meter was used to measure the temperature $\left({ }^{\circ} \mathrm{C}\right)$ and relative humidity $(\%)$ conditions of the DCCs. Apart from the indoor readings outdoor measurements was also carried out

\subsection{Monitoring of Particulate Matter $\left(\boldsymbol{P M}_{10}\right)$ Concentration}

The met-one particle counter was used to measure the number of particles in the selected DCCs. The met-one particle counter is a small, easy to use and completely portable hand-held particle counter that provides fast and accurate measurement of particulate contamination in particles per cubic foot. The particle counter has a NIST traceable calibration in accordance with JIS B 9921 and ASTM F328 andASTM F649. The sampler takes a total of 10 samples after which it averages them to represent the result per location. A conversion factor from the Air Quality Sensor Network for Philadelphia-Data Validation- was used to estimate the $\mathrm{PM}_{10}$ levels in $\mu \mathrm{g} / \mathrm{m}^{3}$.Measurements were taken both indoor and outdoor. The ambient and indoor measurements were determined at two periods of the day between $8 \mathrm{am}-11 \mathrm{am}$ and between $12 \mathrm{pm}-3 \mathrm{pm}$. Measurements were taken three days in a week for 16weeks spanning the rainy and the dry seasons respectively.

PMConcentration $\left(\mu \mathrm{g} / \mathrm{m}^{3}\right)=$ NumberofParticles $\times$ $3531.5 \times$ ParticleMass*

*The mass of a particle in the $\mathrm{PM}_{10}$ channel is $1.21 \mathrm{E}-4$ $\mu \mathrm{g}$

A zero test was caried out using a zero test filter (Met One Part Number G3111) to the GT-321 inlet nozzle. Thezero filter removes $99.99 \%$ of all particles larger than 0.3 micron.

\subsection{Data Analysis}

Data was analysed using SPSS version 15..Descriptive statistics was used to summarize the data while ANOVA was used to assess the variations in mean values of $\mathrm{PM}_{10}$ across the locations and between seasons.Pearson Correlation was also used to establish some relationship between indoor and outdoor $\mathrm{PM}_{10}$ concentration and meteorological parameters.All analyses was done with significant level put at $\mathrm{P}=0.05$ 


\section{Results}

\subsection{Meteorological Conditions}

The indoor temperature and relative humidity conditions for the wet and dry seasons are shown in Tables I and II respectively.As expected the mean dry seaon temperature levels were higher than that of the wet season.In Table II the reverse was the case as the wet season relative humidity was higher than that of the dry season.

Table I. Average Indoor Temperature levels by Season

\begin{tabular}{llll}
\hline Parameter & Time of day & Mean \pm SD $\left({ }^{0} \mathbf{C}\right)$ & p value \\
\hline \multicolumn{2}{l}{ Wet Season Indoor Conditions } & & \\
Temperature & Morning & $28.4 \pm 1.0$ & 0.000 \\
& Afternoon & $32.6 \pm 1.3$ & \\
Dry season Indoor Conditions & & 0.000 \\
Temperature & Morning & $27.5 \pm 1.2$ & \\
\hline
\end{tabular}

Table $1 \mathrm{~b}$ ANOVA for Temperature and Relative Humidity

\begin{tabular}{|c|c|c|c|c|c|c|}
\hline & & $\begin{array}{l}\text { Sum of } \\
\text { Squares }\end{array}$ & df & $\begin{array}{l}\text { Mean } \\
\text { Square } \\
\end{array}$ & $\mathbf{F}$ & Sig. \\
\hline \multirow[t]{3}{*}{$\begin{array}{l}\text { Morning } \\
\text { Relative } \\
\text { Humidity }\end{array}$} & $\begin{array}{l}\text { Between } \\
\text { Groups }\end{array}$ & 8852.48 & 1 & 8852.48 & $\begin{array}{l}236 . \\
026\end{array}$ & .000 \\
\hline & $\begin{array}{l}\text { Within } \\
\text { Groups }\end{array}$ & 7426.26 & 198 & 37.51 & & \\
\hline & Total & $\begin{array}{l}16278.7 \\
4\end{array}$ & 199 & & & \\
\hline \multirow[t]{3}{*}{$\begin{array}{l}\text { Afternoon } \\
\text { Relative } \\
\text { Humidity }\end{array}$} & $\begin{array}{l}\text { Between } \\
\text { Groups }\end{array}$ & 7813.75 & 1 & 7813.75 & $\begin{array}{l}226 . \\
715\end{array}$ & .000 \\
\hline & $\begin{array}{l}\text { Within } \\
\text { Groups }\end{array}$ & 6824.08 & 198 & 34.47 & & \\
\hline & Total & $\begin{array}{l}14637.8 \\
3\end{array}$ & 199 & & & \\
\hline \multirow[t]{3}{*}{$\begin{array}{l}\text { Morning } \\
\text { Temperatur } \\
\text { e }\end{array}$} & $\begin{array}{l}\text { Between } \\
\text { Groups }\end{array}$ & 30.42 & 1 & 30.42 & $\begin{array}{l}21.5 \\
45\end{array}$ & .000 \\
\hline & $\begin{array}{l}\text { Within } \\
\text { Groups }\end{array}$ & 279.56 & 198 & 1.41 & & \\
\hline & Total & 309.98 & 199 & & & \\
\hline \multirow[t]{3}{*}{$\begin{array}{l}\text { Afternoon } \\
\text { Temperatur } \\
\text { e }\end{array}$} & $\begin{array}{l}\text { Between } \\
\text { Groups }\end{array}$ & 40.50 & 1 & 40.50 & $\begin{array}{l}31.7 \\
23\end{array}$ & .000 \\
\hline & $\begin{array}{l}\text { Within } \\
\text { Groups }\end{array}$ & 252.78 & 198 & 1.28 & & \\
\hline & Total & 293.28 & 199 & & & \\
\hline
\end{tabular}

Table II. Average Indoor Relative Humidity levels by Season

\begin{tabular}{|c|c|c|c|}
\hline Parameter & Time of day & Mean \pm SD (\%) & p value \\
\hline \multicolumn{4}{|c|}{ Wet Season Indoor Conditions } \\
\hline \multirow{2}{*}{$\begin{array}{l}\text { Relative } \\
\text { Humidity }\end{array}$} & Morning & $71.0 \pm 7.9$ & \multirow{2}{*}{0.000} \\
\hline & Afternoon & $63.3 \pm 7.2$ & \\
\hline \multicolumn{4}{|c|}{ Dry season Indoor Conditions } \\
\hline \multirow{2}{*}{$\begin{array}{l}\text { Relative } \\
\text { Humidity }\end{array}$} & Morning & $57.7 \pm 3.6$ & \multirow{2}{*}{0.000} \\
\hline & Afternoon & $50.8 \pm 4.2$ & \\
\hline
\end{tabular}

\subsection{Variations in Particulate Matter (PM10) Concentrations}

The $\mathrm{PM}_{10}$ concentration ranged from $19 \mu \mathrm{g} / \mathrm{m}^{3}$ to $536.8 \mu \mathrm{g} / \mathrm{m}^{3}$ in the morning and from $23 \mu \mathrm{g} / \mathrm{m}^{3}$ to $677 \mu \mathrm{g} / \mathrm{m}^{3}$ in the afternoon for the indoor conditions. The daily outdoor $\mathrm{PM}_{10}$ ranged from $12 \mu \mathrm{g} / \mathrm{m}^{3}$ to $406 \mu \mathrm{g} / \mathrm{m}^{3}$ in the morning and from $21.0 \mu \mathrm{g} / \mathrm{m}^{3}$ to $504.21 \mu \mathrm{g} / \mathrm{m}^{3}$ in the afternoon. The difference in concentration between indoor and outdoor readings in the morning showed no statistical significance. In the afternoon however the indoor $\mathrm{PM}_{10}$ concentration significantly exceeded the outdoor concentration.

The peak $\mathrm{PM}_{10}$ readings were recorded in the $5^{\text {th }}$ week and $13^{\text {th }}$ weeks of the wet and dry seasons respectively. A comparison of weekly mean $\mathrm{PM}_{10}$ readings with guideline limit showed both the wet season readings and dry season readings exceeded WHO guideline limits and these results were statistically significant $(\mathrm{P}<0.05)$

The mean $\mathrm{PM}_{10}$ concentration in the wet season was significantly lower than the dry season concentrations (see Table III). The mean indoor/outdoor ratios in the wet season $1.3 \pm 1.0$ and dry season $1.0 \pm 0.2$ both exceeded 1.0 thus indicating a possible indoor pollution source. The range in values observed was broader in the wet season as compared to the dry season though they both had a median concentration of 1 (See Figure 1).

Table III. Indoor and Outdoor Particulate Matter Concentration in the Wet Season and Dry Season

\begin{tabular}{llll}
\hline Parameter & Season & Mean $\pm \operatorname{Stddev}\left(\mu \mathrm{g} / \mathbf{m}^{\mathbf{3}}\right)$ & p-value \\
\hline $\begin{array}{l}\text { Indoor Condition } \\
\text { Particulate Matter }\end{array}$ & Wet & $88.6 \pm 55.6$ & \\
$\left(\mathbf{P M}_{10}\right)$ & Dry & $299.8 \pm 62.9$ & 0.000 \\
$\begin{array}{l}\text { Outdoor Condition } \\
\text { Particulate Matter }\end{array}$ & Wet & $75.2 \pm 43.7$ & \\
$\left(\mathbf{P M}_{\mathbf{1 0}}\right)$ & Dry & $292.1 \pm 44.3$ & 0.000 \\
\hline
\end{tabular}

ANOVA for Particulate Matter $\left(P M_{10}\right)$

\begin{tabular}{|c|c|c|c|c|c|c|}
\hline & & $\begin{array}{l}\text { Sum of } \\
\text { Squares }\end{array}$ & df & $\begin{array}{l}\text { Mean } \\
\text { Square }\end{array}$ & $\mathbf{F}$ & Sig. \\
\hline $\begin{array}{l}\text { indoor } \\
\text { Particulate } \\
\text { Matter } \\
\left(\mathrm{PM}_{10}\right)\end{array}$ & $\begin{array}{l}\text { Between } \\
\text { Groups }\end{array}$ & 2230389.6 & 1 & 2230389.6 & 631.6 & .000 \\
\hline \multirow{5}{*}{$\begin{array}{l}\text { outdoor } \\
\text { Particulate } \\
\text { Matter } \\
\left(\mathrm{PM}_{10}\right)\end{array}$} & $\begin{array}{l}\text { Within } \\
\text { Groups }\end{array}$ & 699224.2 & 198 & 3531.4 & \multirow{5}{*}{1212.9} & \multirow{5}{*}{.000} \\
\hline & Total & 2929613.7 & 199 & & & \\
\hline & $\begin{array}{l}\text { Between } \\
\text { Groups }\end{array}$ & 2352418.4 & 1 & 2352418.4 & & \\
\hline & $\begin{array}{l}\text { Within } \\
\text { Groups }\end{array}$ & 384009.4 & 198 & \multirow[t]{2}{*}{1939.4} & & \\
\hline & Total & 2736427.9 & 199 & & & \\
\hline
\end{tabular}




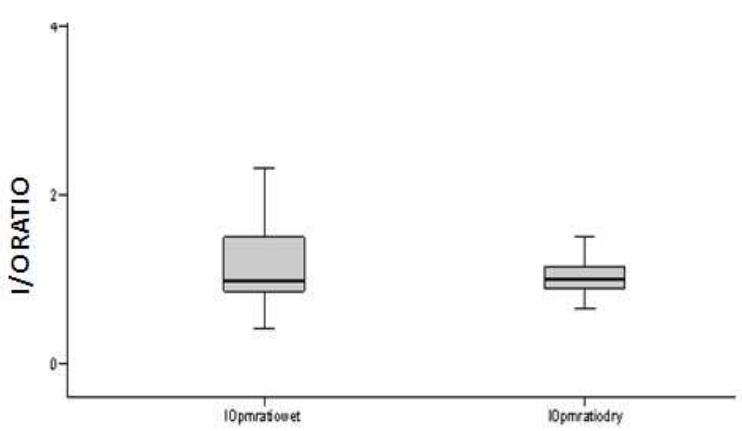

Fig 1. Indoor/Outdoor Ratio (I/O) Wet Season (WS) and Dry Season (DS)

There was a strong positive correlation $\left(\mathrm{r}=0.88, \mathrm{r}^{2}=0.77\right)$ between the indoor and outdoor $\mathrm{PM}_{10}$ concentrations. The uphill pattern of data in figure 2 shows this positive relationship. This could be interpreted as meaning an increase in outdoor $\mathrm{PM}_{10}$ would be followed by a corresponding increase in indoor $\mathrm{PM}_{10}$. There was also a strong negative correlation between indoor $\mathrm{PM}_{10}$ and relative humidity $(r=0.704 ; p=0.000)$ with a coefficient of determination $\mathrm{r}^{2}$ of 0.496 . Fig 3 shows the relationship between Indoor $\mathrm{PM}_{10}$ and indoor Relative humidity with the data showing a downhill pattern indicating that a decrease in relative humidity would be followed by an increase in particulate matter $\left(\mathrm{PM}_{10}\right)$ concentration.

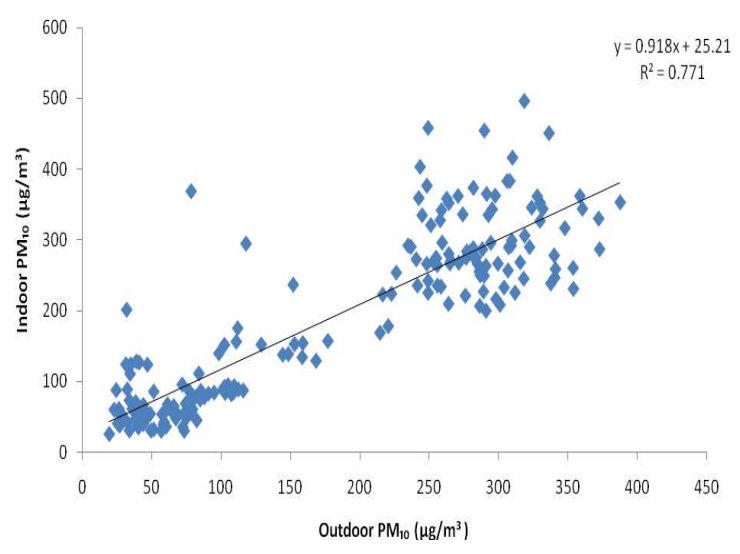

Fig 2. lationship between Indoor $P M_{10}$ and Outdoor $P M_{10}$

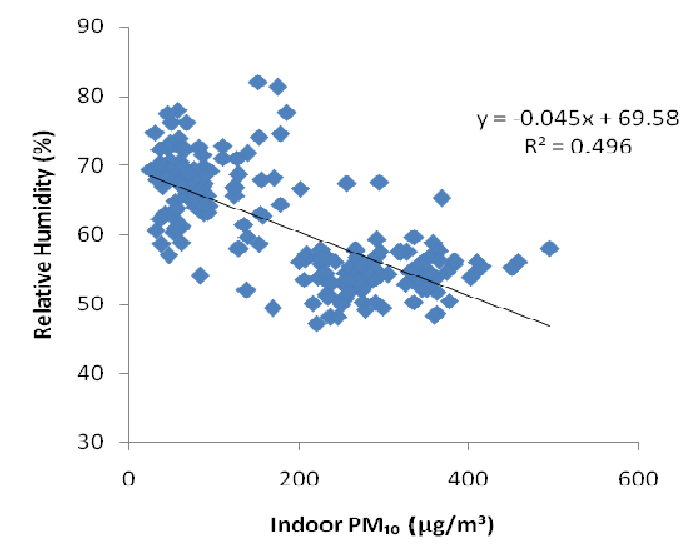

Fig 3. Relationship between Indoor PM10 and Relative Humidity

\section{Discussion}

Meteorological variables have a significant influence on the dispersion of $\mathrm{PM}_{10}$ [6]. The change in pattern of distribution of air pollutants such as particulate matter is predicated on the changing weather conditions. To the best of our knowledge the pattern and seasonal variations in $\mathrm{PM}_{10}$ concentrations has not been investigated in day-care environments in Nigeria. Hence our study assessed the seasonal changes in $\mathrm{PM}_{10}$ load in selected day-care centres in Ibadan, South West Nigeria

The higher particulate matter observed in the dry season was similar to the findings of Abdullah et al. [6] in Malaysia and Massey et al. [16] in India. It was reported that the higher value of $\mathrm{PM}_{10}$ concentration during this period was mainly due to the drier weather condition, stable atmosphere amongst other factors [22]. According to Massey et al., [16] the difference observed here was attributed to an increase human activity and also to low wind speeds in comparison with other seasons.

Studies by Pudpong et al., [7] also associated high particulate concentration with increased human activity stating that people accessing indoor environments may carry them on the surface of their clothes or even shoes. The coefficient of determination $\left(r^{2}\right)$ between indoor and outdoor data is often used as an indicator of the degree to which particulate matter measured indoors is attributed to infiltration from outdoors [15].

The strong correlation between indoor and outdoor particulates at both periods of measurements maybe linked to the method of ventilation and the proximity of the daycare centres to roads. It raises questions about how effective the ventilation strategy is in diluting the particulates. Sanitary practices such as cleaning, dusting within and around the daycare centres may also affect the particulate matter concentration [15].A study by ParttiPellinen et al[13] indicated that indoor levels of particulate matter were reduced when mechanical filtration was installed (indoor-outdoor ratio of 0.3 ).

The dry season I/O ratio was similar to the findings of Kulshreshtha et. al [15]. The I/O ratio which was greater than one was attributed to activities such as dusting, cleaning re-suspension and playing of kids indoors. Temperature and wind direction are two main factors which are said to have an effect on particulate matter concentration [19]. Several studies indicated that total suspended particles (TSP) and $\mathrm{PM}_{10}$ concentration in air is affected by wind speed, wind direction, solar radiation, relative humidity and rainfall [20,21, 22].

In our study positive correlation was observed between temperature and $\mathrm{PM}_{10}$ which is consistent with findings of Abdullah et al [6]. The negative correlation between $\mathrm{PM}_{10}$ and relative humidity was also consistent with findings of Abdullah et al [6]. Temperature affects fuel usage and ambient chemical reactions and relative humidity largely removes pollutants from the atmosphere [22, 23]. 


\section{Conclusion}

The results showed distinct variation in particulate matter concentration in the two seasons. $\mathrm{PM}_{10}$ concentration was highest in the dry season and exceeded WHO guideline limit. The high $\mathrm{PM}_{10}$ concentration observed suggests a poor indoor air quality condition in the day-care centres which may expose the children to associated health risks. Routine indoor air quality monitoring and good sanitary practices in day-care centres are therefore advocated.

\section{Acknowledgements}

The authors are grateful to all the children and care givers at the day-care centres whose facilities were examined .We are also grateful to the Department of Environmental Health sciences for all the technical support.

\section{References}

[1] UNESCO International Bureau of Education (IBE) Geneva, (Switzerland); Country profile prepared for the Education for All Global Monitoring Report 2007 Strong Foundations: Early Childhood Care and Education Nigeria Early Childhood Care and Education (ECCE) programmes2006.

[2] C. Howes .The Impact of Child Care on Young Children (02) University of California at Los Angeles, UNITED STATES , 2003 (Published online)

[3] WHO Global plan of Action for Children's Health and the Environment accessed online at , 2010 , www.who.int/ceh/cehplanaction10_15pdf

[4] Canadian Partnership for Children's Health and Environment (CPCHE) - Advancing Environmental Health in Child Care Settings. A Checklist for Child Care Practitioners and Public Health Inspectors, 2010.

[5] A. Manandhar, S.C. Lee, K.F. Ho, W.T. Hung, G.R. Joshi. etc. Identification of Indoor and Outdoor Particulate Concentration and its Chemical Composition in Kathmandu Valley, 2010

[6] N.A.Abdullah, H.S. Siti , Y.Y. Toh, H.S. Afizal . Maznorizan Mohamad The Study of Seasonal Variation of $\mathrm{PM}_{10}$ Concentration in Peninsular, Sabah and Sarawak Published online September 2011

[7] N. Pudpong, R.Krassi, K.Nipapun. Indoor Concentrations of PM10 and Factors Influencing Its Concentrations in Day Care Centres in Bangkok, Thailand Asia Journal of Public Health Journal homepage: http://www.ASIAPH.org January - April 2011 Vol.2 No. 1

[8] C. Penard-Morand, D.Charpin, C.Raherison. Long-term exposure to background air pollution related to respiratory and allergic health in schoolchildren. ClinExp Allergy 2005; 35:1279-1287.

[9] D.W. Dockery ,C.A. Pope ,X. Xu , J.D. Spengler, J.H. Ware, M.E. Fay , B.G. Ferris Jr, F.E. Speizer. An association between air pollution and mortality in six U.S. cities. N Engl J Med. 1993; 9; 329(24):1753-9.

[10] J.M Peters, E.Avol, W.Navidi , S.J. London ,
W.J.Gauderman , F.Lurmann , W.S. Linn H. Margolis,E.Rappaport ,H. Gong, D.C. Thomas. A study of twelve Southern California communities with differing levels and types of air pollution. I. Prevalence of respiratory morbidity. Am. J. Respir. Crit. Care Med. 1999; 159 (3): 760-7.

[11] J. Schwartz, L.M. Neas. Fine particles are more strongly associated than coarse particles with acute respiratory health effects in schoolchildren. Epidemiology. 2000; 11(1):6-10.

[12] A. Le Tertre, S. Medina , E.Samoli , B. Forsberg ,P.Michelozzi , A.Boumghar , J.MVonk , A. Bellini , R. Atkinson , J.G. Ayres , J. Sunyer , J. Schwartz , K.Katsouyanni . Short-term effects of particulate air pollution on cardiovascular diseases in eight European cities.J Epidemiol Community Health. 2002; 56(10):773-9

[13] L. Partti-Pellinen, O. Martilla, A.Ahonen, O.Suominen, T.Haahtela. Penetration of nitrogen oxides and particles from outdoor into indoor air and removal of the pollutants through filtration of incoming air. Indoor Air 2000; 10 (2): 126-32.

[14] L. Laquatra , L.E. Maxwell and M. Pierce M. INDOOR AIR POLLUTANTS, LIMITED RESOURCE HOUSEHOLDS AND CHILDCARE FACILITIES Department of Design and Environmental Analysis, Cornell University, Ithaca, NY, USA Proceedings: Indoor Air 2002

[15] P. Kulshreshtha, K.Mukesh. Indoor exploratory analysis of gaseous pollutants and respirable particulate matter at residential homes of Delhi, India Department of Civil Engineering, Indian Institute of Technology Delhi, Delhi 110016, India Atmospheric Pollution Research 2 (2011) 337-350 doi: 10.5094/APR.2011.038

[16] D. D .Massey , A. Kulshrestha, A.Taneja.A Study on Indoor/Outdoor Concentration of Particulate Matter in Rural Residential Houses in India. 2009 Second International Conference on Environmental and Computer Science978-0$7695-3937-9 / 09 \quad \$ 26.00 \quad$ (C) 2009 IEEE. DOI 10.1109/ICECS.2009.45

[17] H.A.Ajimotokan, H.A, Oloyede, L.A, Ismail, M.E Influence of Indoor Environment On Health And Productivity New York Science Journal, 2009, 2(4), ISSN 1554-0200 http://www.sciencepub.net/newyork sciencepub@gmail.com

[18] National Population Commission: The Breakdown of the National and State Provisional Population Totals 2006 Census. Federal Republic of Nigeria Official Gazette.No.24, Vol.94. 2006. Published by The Federal Government Printer, Lagos, Nigeria.

[19] K.L.Yang. Spatial and seasonal variation of PM10 mass concentrations in Taiwan. Atmospheric Environment 36 (2002) 3403-3411 Institute of Earth Sciences, Academia Sinica, Taiwan, ROC.

[20] P.Alpert,Y. Kaufman, Y. J., Shay-El, Y., Tanré, D., Da Silva, A. S., Schubert, S. and Joseph J. H., Quantification of dustforced heating of the lower troposphere. Nature, 1998. 395, $367-370$.

[21] C.Monn, Exposure assessment of air pollutants: A review on spatial heterogeneity and indoor/outdoor/ personal exposure to suspended particulate matter, nitrogen dioxide and ozone. Atmos. Environ., 2001, 35, 1- 32. 
[22] D. Giri, M.V.Krishna and P.R.Adhikary. The Influence of Meteorological Conditions on PM10 Concentrations in Kathmandu Valley Int. J. Environ. Res., 2008, 2(1): 49-60.
[23] Seinfeld and Spyros, 1998, Seinfeld, J. and Spyros, N., 1998 Atmospheric chemistry and physics from air pollution to climate change. New York, John Wiley \& Sons, Inc. 